\title{
The Analysis of Translated Hedges in Trump's Political Speeches and Interviews
}

\author{
Areej M. A. AL-Jawadi ${ }^{1}$ \\ ${ }^{1}$ Department of Basic Sciences, College of Dentistry, University of Mosul, Mosul, Iraq \\ Correspondence: Areej M. A. AL-Jawadi, Department of Basic Sciences, College of Dentistry, University of \\ Mosul, Mosul, Iraq. E-mail: areej_m2018@uomosul.edu.iq
}

Received: February 2, 2021

Accepted: January 24, 2022 Online Published: February 13, 2022

doi:10.5539/ijel.v12n2p47

URL: https://doi.org/10.5539/ijel.v12n2p47

\begin{abstract}
This study tackles the analysis of translated hedges, in Trump's political speeches and, interviews in the data, which have taken from three different political interviews of press conferences; that have conducted with U.S. President Donald Trump about coronavirus with their translations into Arabic. Therefore, the study has adopted Fraser's classification of hedges and tries to apply it into the data. Moreover, the study has applied statistics to find out that illocutionary force hedges have widely used in Trump's political speeches and interviews more than the propositional hedges according to Fraser's classification of hedges. Thus, hedges can be considered as one of the most important linguistic phenomena because it can widely be used as a way of expressing points of view in political discourse. In addition to that, this linguistic phenomenon can be used by variety speakers of people in their daily life such as doctors, teachers, lawyers, but in particular politicians in their speeches, TV-interviews and press-conferences.
\end{abstract}

Keywords: discourse analysis, propositional content, hedges, context of situation

\section{An Introduction to Hedge}

Hedges is a linguistic phenomenon that has widely used in political texts, speeches, and interviews in both English and Arabic linguistic communities. Hedges may vary regarding their usages matters due to the differences in social, psychosocial and cultural manifestations. Lakoff (1972, p. 195) introduced the term hedge for the first time to refer to the words whose job is to make things more or less fuzzy. It has used to refer to many related matters, such as: "lack of full commitment", vagueness, politeness, tentativeness, "approximation", possibility, "indeterminacy" and indirectness. Hedges also presented in 1987 by Brown and Levinson (2000, p. 145) stated that the study of hedges refers to the phrases that signify the predicate of member of a noun phrase. It usually manages the form of propositional aspects of communication. Salager-Meyer in (1994, p. 150) implied that purposive vagueness and tentativeness associated with hedges. Hyland (1998, p. 428), claimed that hedging has considered to be the best indication "of an unwillingness to make a complete commitment to the truth of a proposition, most particular regarding new knowledge". Martin. M (2008, p. 134), implied to hedge as an expression that mitigates and reduces the strength of the assertions in which the speaker and writer make. Fraser in (2010, p. 201) has reported "that hedging is a rhetorical strategy where it signals a lack of a full commitment either" to content mitigation, or force mitigation. So, according to Fraser, a participant presents a shortage of "commitment to the truth" conditioned of the speech.

\section{The Definition of Hedges}

According to Fraser and from what have mentioned before, one can define hedge as a rhetorical strategy by which a participant shows a lack of commitment to the truth condition of the utterance. Thus, pragmatic hedges have used to weaken the truth values of utterances. For example:

(SL) English: I don't believe I'm studious.

(Content mitigation)

(TL) Arabic: "“ألأعتقد بأنني مسؤول"
I'm not studious.

(Force mitigation)

"لست مسؤولاً،

\section{The Usages, Functions and Purposes of Hedges}

According to Hovy (2004, p. 2), Weinerich was the first who examined usages of hedges and called them 
"metalinguistic operators" whereas Lakoff called them hedges, showing that they "are some lexical expressions that are used to shift the borderlines" (1972, p. 195). Lakoff (1973, p. 151), has not considered the "effect of context on the meaning, function of words", and provided a list of concepts referring that, "the boundaries of these concepts in any natural language are fuzzy and not clear-cut". On the contrary, Clemen $(1997,1998)$ was the one who adopted the effect of speech into his consideration and stating that hedges will be accomplished by "using utterances in context rather than by straightforward statement" (ibid). Based on this, Clemen "defined hedges as everything that in a way modified the truth-condition of a sentence, the commitment of the participant or commented on the sentence as such". On the other hand; Fraser (2010, p. 202), takes the effect of context into account, in the case of using hedge by a speaker. In fact, Fraser makes the intention of action so that to set the force of the whole valuable speech. Actually, hedges have used to decay the veracity value of the speech. For example:

\section{(SL) English: "I don't think I'm good" and "I'm not good"}

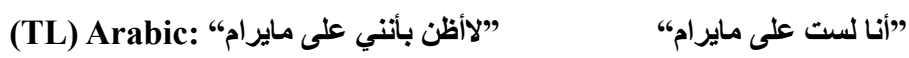

Therefore, according to Fraser (ibid, p. 205), hedges have two main general purposes: First, "attenuation of an undesirable effect on the hearer; hence being more polite in the utterance". Second, "avoiding providing the expected information; thus, being evasive and vague in the utterance".

No unanimous agreement about the functions of hedges because each one of the hedging device performs a particular function gratified by a specific device. According to Lakoff (1972-1975), there are "two main aspects of using hedges: showing some kind of probability and polite attitudes. Hübler, indicated" that hedges are valuable linguistic devices that serve many functions, such as expressing politeness, showing uncertainty and indirectness". Brown and Levinson (1987) explained how "hedges" refer to "the avoidance" strategy among views, and negative politeness, that "aims at saving the face of the interlocutors". Likewise, Hyland submitted that the tools of hedges contain two "great facts": How the person is cautious while he/she is expressing his/her intellect, and discussing them in a "diplomatic way". Moreover, Fraser (ibid, p. 205), stated, "that hedges have used for many purposes, such as showing both positive and negative politeness, protecting one's ego", avoidance strategy, "getting rid of responsibility", "showing mitigation", and "appearing modest and less powerful".

\section{Political Discourses' Hedges}

Most politicians tried to use hedges within their speeches, interviews, presidential debates... etc., so that to clarify uncertain and the non-commitment to a speech, and also to reflect an inherent component of fuzziness. On this basis, hedges in political discourse are a means of expressing thoughts and opinions. Simply, it is an exponent of diplomacy, politeness, and respect. There are three types or groups of hedge devices that can be used according to Missikova (2008, pp. 76-79), the first type or group of hedges is the hedging items of truth conditions which use phrases such as a "sort of, actually, kind of, etc." The second type of hedging device is the one that does indicate "the awareness of quantity of maxims" which distinguish between over and under information point out within the quality maxim. The third type or group, is the minimum numbers of hedges that can be used to refer "the maxim of manner and relation" for example: as they said.

President George W. Bush in 2007. The survey has found "that many hedge-type linguistic items did not serve as hedging devices". In addition to that, Fraser observed many cases of neutral hedges that did effective topic. Fraser claimed that there was no reference that hedging used for polite attitudes, but rather conveying a less accurate.

Is a matter of fact, few studies have tackled hedges phenomenon in political texts, especially the hedges that have produced by "American and European leaders". However, No studies have ever tackled hedges in political discourse produced by Arab leaders or politicians.

\subsection{Translation of Hedges in Political Texts}

Fraser indicated that Partington can be the only one who has done researches and studies about hedges in political texts; since that, not many studies have made. In fact, Partington has referred "that hedging is only one of the mapping for evading, others being bald on-record refusal to answer, claims of ignorance, referring the question, refusal to explain, stating the answer is famous, and saying that the question has answered already" (2010, p. 206). In political texts, hedges' translation has tackled in a few studies for many reasons, and the most important one is the sensitivity of political texts and their translations to the context makes the task of translator more difficult and critical. As a result, the product might have unpredictable "consequences". For this reason, Baker (2006) has indicated "that political conflicts involve translation and interpretation. This issue gets worse when translating "hedges" which are used by the original author to evade responsibility for what they say or to 
attenuate the force of the utterance". For this reason, Newmark has emphasized "that a translator should be very cautious and objective in translation of authoritative texts; hence political text" (1982). Moreover, the translator should be "sensitive and a critic of language" (ibid, p. 375). One of the most indispensable studies that have conducted about the translation of hedges in political texts; is the one by Schäffner (1988, p. 179) and her article entitled "Hedges in Political Texts: A Translational Perspective". She used Pinkal's classification of hedges believing that in political discourse, hedges devices' function is to "relieve the authors of some responsibilities for their statement".

\subsection{Hedges in Political Speeches}

The usages of hedges in political speeches have studied and declaimed by "Obama and George W. Bush.: pre-election" and postelection. Laurinaityte has found that some hedges such as "modal verbs, modal lexical verbs, special passive voice constructions, and introductory phrases" have used commonly in pre-election than in post-election speeches, but "approximates, adjectival, adverbial and nominal modal phrases" have used in postelection speeches.

\subsection{Translation of Hedges in Political Speech}

Mundy (2008, p. 42) stated that, Fairclough has believed that the "ideology" will be much better expressed over "language"; especially when it is "disguised", since that language has regarded as "social practice". Hedging has considered to be as one of the most important ways to express and imply ideologies of both the individual and society, using them at the same time. Based on this, the speaker and author try to express their dominant ideologies of the society and hedging their responsibility for what they say or write. Therefore, the phenomenon of hedging can be considered as a model of style over where "ideology" can be expressed.

The translation of hedges in a political speech has considered to be critical; specially, those of the president's speech since that the president is the speaker on behalf of the people, expressing the style, ideology of that country. Based on this, any changes in the lexical style of hedges, will lead to changes in the ideologies expressed by the SL speaker and hence their translations as a result. Therefore, Hedges' usages have been extremely critical for their doctrinaire even in the same speech; for example, the "intralingual translation" of using "Jakobson's terms", which had terrible "consequences" that have led to war. For instance, rewriting a file which had prepared by the advisers of war's criminal; the ex-UK Prime Minister Tony Blair; and result in a war against Iraq in 2003. According to this, "the hedge, "might be able to", which made by the intelligence service, "Iraq might be able to launch chemical, and biological weapons, within 45 minutes" has rewritten over, and over"; so that to reduce hedging from uncertainty to certainty. As a result, "the intelligence has suggested changes to the more certain indicates and conditional would be able to become may be and finally shifts to simple indicative are". For this reason, "the reader will believe that the speaker has been certain of the truth value of the proposition" (Munday, 2012, p. 6). In this regard, translation of hedges concerning politics and the critical role of the translator will be shown.

\subsection{Hedges in Political Interviews}

The usages of hedges in political interviews had discussed in four political interviews by Jalilifar and Alavi (2011). They were chosen and conducted by CNN and BBC with former U.S. Presidents George W. Bush, Jimmy Carter, the senior member of Zimbabwe's main opposition party David Coltart, and Sarah Palin McCain the running mate for the position of Vice President. The study has found that there has been a relation between the quantity and quality of hedging devices and the degree of political power. Researchers have also noticed that, the types of questions which the interviewers asked and their attitudes towards the interviewees have influenced the patterns of hedges which were used by the speakers. Moreover, they claimed that, the use of hedging devices in the political interview is an indication of the use of positive and negative politeness strategies.

\subsection{Hedges in Political Debates}

Concerning hedges in political debates, some researchers such as Al-Rashady have found and identified hedging devices and their functions in the presidential debates between Barack Obama and John McCain in 2008 US election cycle. He has drawn a conclusion that "modal auxiliary verbs; modal lexical verbs; adjectival, adverbial, nominal modal phrases and approximates" were the most dominant hedging devices. In addition to that, the intentional purposes of the speaker play the main role in determining the function that's served.

\section{Men and Women Hedges}

Lakoff (1973) has implied that "women have used hedges more than men so that to show "uncertainty'...". Holmes has also found "that women used hedges and tag questions more than men". On the other hand, Pellby (2013, p. 29), indicated that women use hedges more than men in her study: Hedging in Political Discourse; for many reasons; especially signaling the uncertainty. Moreover, she stated that "the mostly used hedging devices 
for women are the epistemic modal function and hedges which seek confirmation, indicating that women signaled uncertainty and wanted confirmation more often than men". Results have also found that men are dominating the political discourse more than women, since men have given more time for speaking than women during the meeting. The researcher has used a classification based on the various functions of hedges, such as the epistemic modal function, the affective function which seek confirmation and shields. Based on what has mentioned before; the essential functions of hedges are either to show politeness or uncertainty, depending on both context and intonation in the situation.

\section{Classification of Hedges}

Many scholars have proposed different classifications of hedges. Fraser's classification of hedges has considered to be the most important of all.

\subsection{Fraser's Classification of Hedges}

Fraser believed "that the focus of hedges has varied from a word, to a phrase, the entire sentence, or the intended illocutionary force of the utterance, or its perlocutionary effect" (2010, p. 203). Therefore, he has introduced his following classification of hedges based on the distinction between the content and force hedging only.

\subsubsection{Propositional Hedges}

Propositional hedges such as: occasionally, about, almost, kind of, largely, more, less, mostly, often, pretty much, rather, really, regular, etc.

\subsubsection{Hedges' Illocutionary Forces}

Fraser (2010, pp. 204-205), indicated that illocutionary force hedges will include the following:

1) Impersonal pronouns: One just doesn't do that.

2) Concessive conjunctions such as: although, though, while, whereas, even though, even if... etc.

3) Hedged performative: I must ask you to stay home.

4) Indirect Speech Acts: Could you speak nicely!

5) Introductory phrases: to our knowledge, I believe, we feel, it is our view that.

6) That: I believe that she is here. Believe and think are hedges only when they express a verifiable fact and not an opinion (Schäffner, 1988, p. 187).

7) Modal adverbs perhaps, possibly, probably... etc.

8) Modal adjectives: possible, probable, un/likely... etc.

9) Modal noun: assumption, claim, possibility, suggestion... etc.

10) Modal verbs: might, can, would, could... etc.

11) Epistemic verbs: seem, appear, believe, assume, suggest, think... etc.

12) Negation: Didn't Harry leave, i.e., I think Harry left; I don't think I'm going. Vs. I'm not going.

13) Reversal tag: She's coming, isn't she?

14) Parenthetic construction: The party is here, I guess.

15) If clause: If true, we're in a big problem.

16) Agentless Passive: Many of the troops were injured. By $\varnothing$

17) Conditional subordinators: as long as, so long as, assuming that, given that... etc.

18) Progressive form.

19) Tentative Inference.

20) Conditional clause implying permission such as, if you don’t mind my saying so, if I may say so... etc.

21) Conditional clause as a metalinguistic comment such as: if that's the right decision... etc.

22) Conditional clause which expresses "uncertainty" of the extra linguistic knowledge that should be available for the right interpretation of the words in the speech, such as, if he's right, in case she doesn't remember... etc.

23) Comments of metalinguistic knowledge. e.g.: Strictly, Not to mention the, precisely, rightly, nearly, around, etc.

Fraser also indicated Salager-Meyer's classification of "Devices of Compound Hedges" in (1995) as the in the 
following:

a) Modal for Hedging Verbs

b) Hedging verb with hedging adverb/adjective

c) Double hedges

d) Treble hedges

e) Quadruple hedges.

\section{Data Analysis}

The data of this research have been collected from the interviews of the press conferences that have been conducted with U.S. President Donald Trump about coronavirus.

1) 'You're a terrible reporter': Trump throws tantrum over question about coronavirus fears.

\section{The Guardian Sat 21 Mar 2020 06.57}

The data of this research have collected from the interviews of the press conferences that were conducted with U.S. President Donald Trump about coronavirus.

1) 'You're a terrible reporter': Trump throws tantrum over question about coronavirus fears.

The Guardian Sat 21 Mar 202006.57

Donald Trump has thrown an extraordinary tantrum on live television, lambasting a reporter who challenged him for raising hopes about a coronavirus treatment. States ask Trump to deploy military to help fight coronavirus pandemic Peter Alexander, White House correspondent at NBC News, asked the US president: "What do you say to Americans, who are watching you right now, who are scared?"

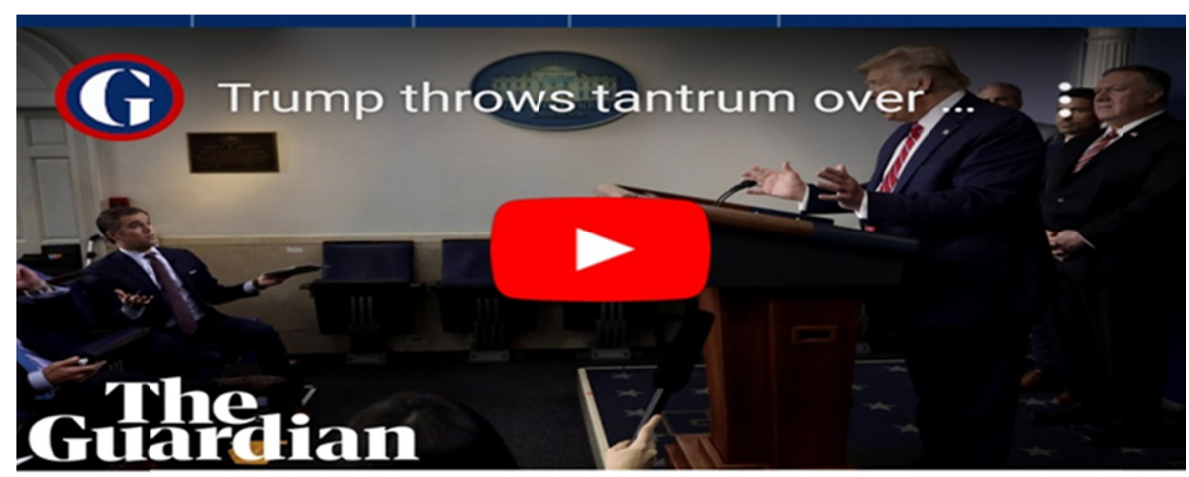

- 'You're a terrible reporter': Trump throws tantrum over question about coronavirus fears - video

Donald Trump Trump throws tantrum over coronavirus question: 'You're a terrible reporter'

Figure 1. 'You're a terrible reporter.'

Erupting in anger, Trump unleashed a tirade: "I say that you're a terrible reporter. That's what I say. I think it's a very nasty question and I think it's a very bad signal that you're putting out to the American people."

In the above stated quotes two kinds of hedges can be seen clearly according to Fraser's classification. The first kind is the 'Illocutionary force hedges' which can be seen in both the 'metalinguistic comment': I say that you're a terrible reporter. That's what I say, and the epistemic verb 'think' that has used twice in: I think it's a very nasty question and I think it's a very bad signal ...... etc. Moreover, illocutionary force hedge can also be found in 
'Negation' I think it's a very nasty question and I think it's a very bad signal where the opposite can be (I don't think it's a very nice question and I don't think it's a very good signal). The second kind is 'propositional hedge' which can be seen in the use of (very) twice in very nasty question and very bad signal. According to Salager-Meyer's classification of "compound hedging devices" in 1995 which has indicated by Fraser; the use of the (metalinguistic comment, epistemic verb, negation and propositional hedges) together in the above stated quote called Quadruple Hedges. So in this conference, president Trump has thrown an extraordinary temper tantrum over a question about COVID-19 fears; because he has been trying very hard to send positive messages of hope to the American people; in time the media are scrambling to sow terror and fear among people. In addition to that, president Trump is referring to the drug of chloroquine and hydroxychloroquine as a possible treatment in an attempt to reach any spark of hope to survive deadly COVID-19 by saying: "It might(work) or might not(work)" he said on Friday. "I feel good about it..."

Safwat $(2018$, p. 2) has referred in her research to the connection between heading and modality and how Lyons (1977) defined epistemic modality. Hedging has typically linked to modality, mostly to epistemic type of modality. Epistemic modality can be expressed in several ways. Lyons (1977) defined epistemic modality as any utterance in which the speaker explicitly qualifies his commitment to the truth of the proposition expressed by the sentence he utters, whether this qualification has made explicit in the verbal component... or in the prosodic or paralinguistic component (Lyons, 1977, p. 797).

Based on this, hedges will be found in the following:

1) "It might or might not" Illocutionary force hedges (Modal verbs (epistemic modality), Negation).

2) "I feel good about it" Propositional hedges.

"You're doing sensationalism.... Let me just tell you something ... That's really bad reporting. You ought to get back to reporting."

Another hedge can also be found, where president Trump has snapped to Peter Alexander NBC News' reporter by saying: "You're doing sensationalism..."; when Alexander asked for Trump's message to people who are feeling scared; meanwhile, president Tramp was trying to send hope's messages, and positive signals to the American people, but media were constantly playing a negative role, by exaggerating, and making things look harder. According to Fraser's classification, this is an Illocutionary force hedges by using (the progressive form You're doing) as in the above stated. Again, in the same place, the use of the (modal verb) "ought to get back to...." which is Illocutionary force hedges. Moreover, illocutionary force hedge also has found in the use of the (Impersonal pronoun) something, which is a singular indefinite-thing pronoun according to Fraser's classification. Propositional hedges can also be seen in Trump saying: "That's really bad reporting" based on Fraser's classification. Trump claimed, "I've been right a lot," and barked at Alexander: "You ought to be ashamed of yourself." Again, the use of the (modal verb) "ought to be ashamed of ...." which is Illocutionary force hedges. Concerning the Translation, the research has found three different translations into Arabic taken from the net as the following:

\section{(SL) English}

"I say that you're a terrible reporter. That's what I say. I think it's a very nasty question and I think it's a very bad signal that you're putting out to the American people. The American people are looking for answers and they are looking for hope, and you're doing sensationalism and the same with NBC and Concast. I don't call it Comcast, I call it Con-cast. Let me just tell you something... That's really bad reporting. You ought to get back to reporting instead of sensationalism. Let see if it works... it might and it might not. I feel good about it, but who knows... I've been right a lot... Let see what happen."

\section{(TL) Arabic}

1) The first translation is taken from (News السياسة) (Politics News) by Suliman Al-Shekh :

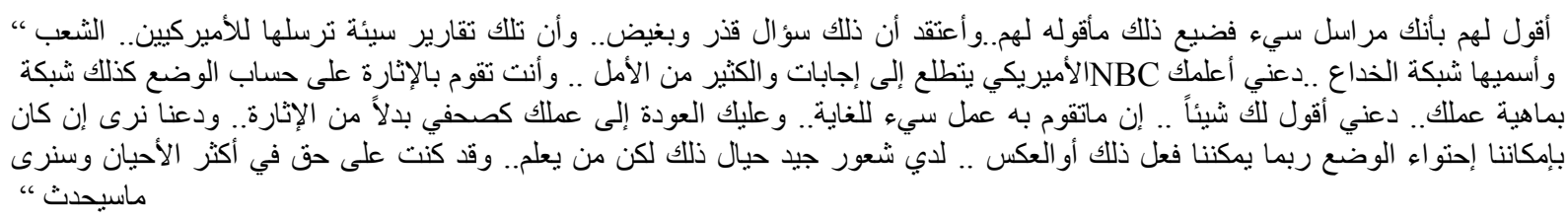

2) The second translation is taken from AnaAlaraby TV:

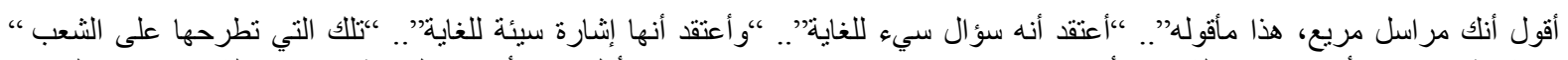

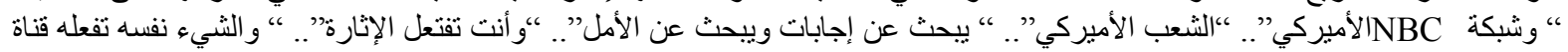




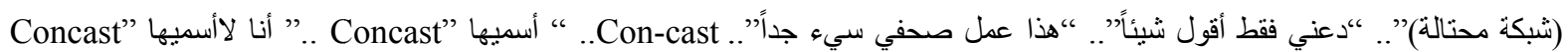

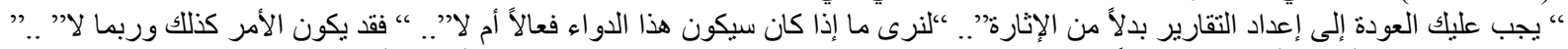

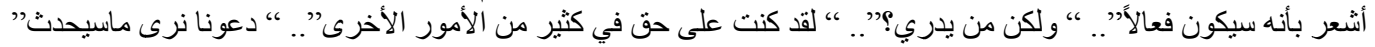

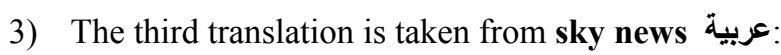

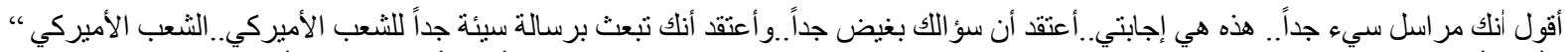

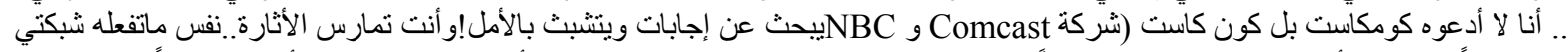

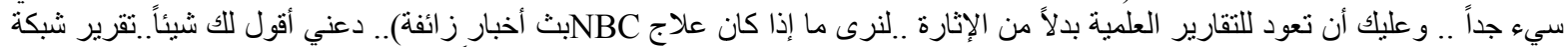

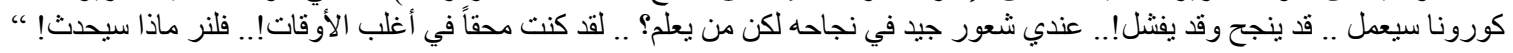

When analyzing and comparing the three translations; the research has found many mistakes as the following:

- The first translation has translated hedges in "I think it's a very bad signal that you're putting out to the American people." into:

أعتقد بأنها : and this is not correct translation since it should be translated into , وأن تللك تقارير سيئة ترسلها للأميركيين إثارة سيئة للغاية تلك التي ترسلها للثعب الأميريكي.

- The third translation has translated hedges in “..... and you're doing sensationalism” into which is a very bad translation in Arabic, comparing to the second translation which contains the

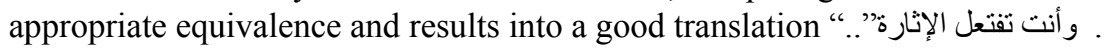

- In the third translation, the translator has committed a terrible mistake by translating the hedges in "You ought to get back to reporting." into:

و وليك أن تعود للتقارير العلمية بدلاً من الإثارة which has nothing got to do with right meaning; in that , the English text does not contain any word "scientific".

In the contrary of the second translation by AnaAlaraby TV which is very good translation since the hedge has been translated into:

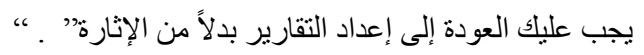

- Based on what has been stated before; the research has found that the second translation by AnaAlaraby TV is the best one.

\section{2) 'Not racist at all': Donald Trump defends calling coronavirus the 'Chinese virus'}

The phrase "Chinese virus" has used for the first time by president Trump referring to COVID-19, since the virus has come from China. A conference's interview published on 18 Mar 2020 has made with the president Trump; where he has dismissed accusations that his use of the term 'Chinese virus' to refer to the coronavirus is racist. Speaking at his daily coronavirus taskforce briefing, he said it was 'not racist at all'. It comes from China; I want to be accurate.'

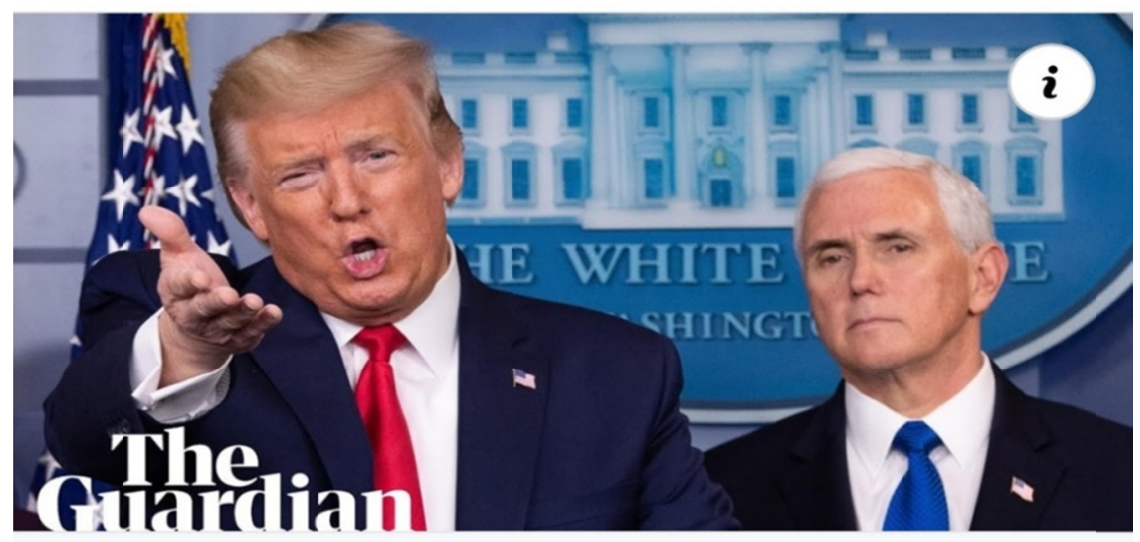

\section{YOUTUBE.COM}

\section{'Not racist at all': Donald Trump defends} calling coronavirus the 'Chinese virus'

Figure 2. 'Not racist at all' 
Based on this, an illocutionary force hedge can be found in the use of negation 'Not racist at all'; in the contrary president Trump admitted that he has great love for all the people in the country (USA), but at the same time president Trump defends calling COVID-19 the Chinese virus for two reasons: first, because it has come from China and this indeed has asserted by the fugitive Chinese virologist Li-Meng Yan (MD, PhD) when first; she has claimed that the coronavirus was laboratory manufactured in the Chinese city of Wuhan, and second, when she has published a new scientific research in (zenodo website), September 14, 2020 "Unusual Features of the SARS-CoV-2 Genome Suggesting Sophisticated Laboratory Modification Rather Than Natural Evolution and Delineation of its Probable Synthetic Route.
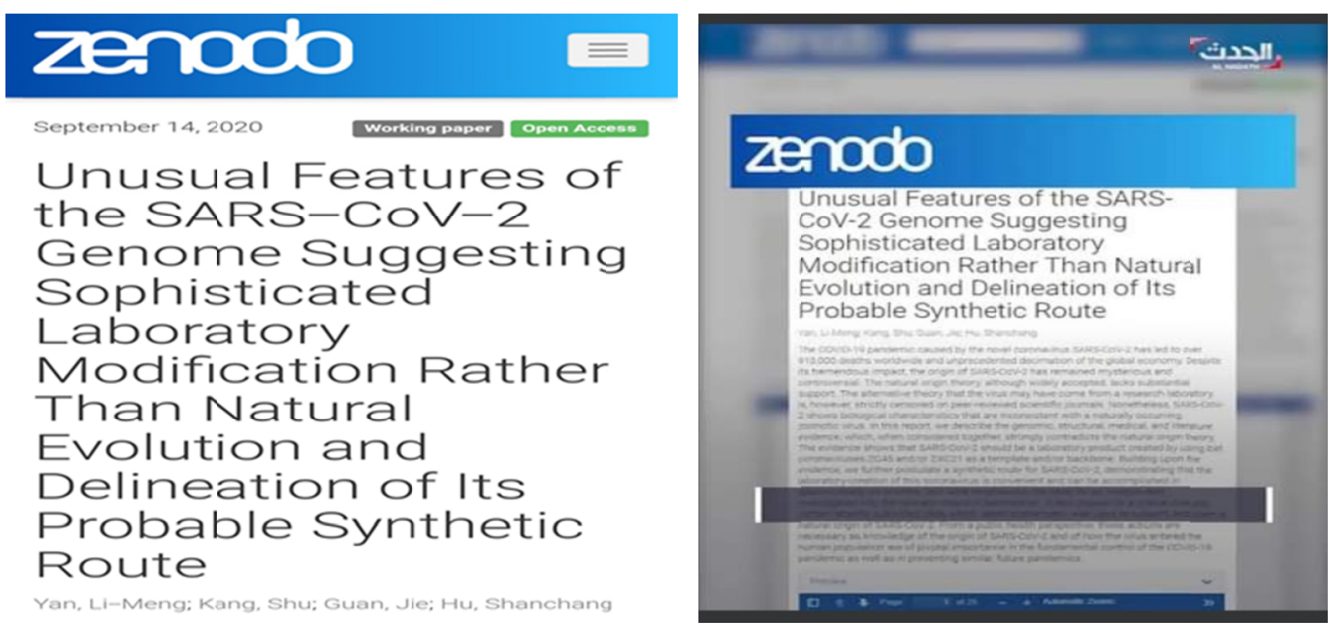

Unusual Features of the SARS-CoV-2 Genome Suggesting Sophisticated
Laboratory Modification Rather Than Natural Evolution and Delineation
of Its Probable Synthetic Route

Li-Meng Yan $(\mathrm{MD}, \mathrm{PhD})^{1}$, Shu Kang $(\mathrm{PhD})^{1}$, Jie Guan $(\mathrm{PhD})^{1}$, Shanchang Hu $(\mathrm{PhD})^{1}$

${ }^{1}$ Rule of Law Society \& Rule of Law Foundation, New York, NY, USA.

Correspondence: team.Imyan@gmail.com

Abstract

The COVID-19 pandemic caused by the novel coronavirus SARS-CoV-2 has led to over 910,000 deaths worldwide and unprecedented decimation of the global economy. Despite its tremendous impact, the origin of SARS-CoV-2 has remained mysterious and controversial. The natural origin theory, although widely accepted, lacks substantial support. The alternative theory that the virus may have come from a research laboratory is, however, strictly censored on peer-reviewed scientific journals. Nonetheless, research laboratory is, however, strictly censored on peer-reviewed seientific journals. Nonetheless, SARS-COV-2 shows biological characteristics that are inconsistent with a naturally occurring, zoonotic virus. In this report, we describe the genomic, structural, medical, and literature evidence, which, when considered together, strongly contradiets the natural origin theory. The evidence shows that SARS-CoV 2 should be a laboratery product create and/or backbone. Building upon the evidence, we further postulate a symthetic route for SARS-CoV-2, demonstrating that the laboratory-creation of this coronavirus is convenient and can be accomplished in approximately six months. Our work emphasizes the need for an independent investigation into the relevant rescarch laboratories. It also argues for a critical look into certain recently published data, which, albeit problematic, was used to support and claim a natural origin of SARS-CoV-2. From a public health perspective, these actions are necessary as knowledge of the origin of SARS-CoV-2 and of how the virus entered the human population are of pivotal importance in the fundamental control of the COVID-19 pandemic as well as in preventing similar, future pandemics.

Figure 3. A new scientific research in (zenodo website), September 14, 2020 "Unusual Features of the SARS-CoV-2 Genome published by Chinese virologist Li-Meng Yan (MD, PhD) 
Second reason, is that China tried to say that coronavirus has caused by American soldiers and that can't happen; it's not going to happen not "as long as I'm the president." said president Trump. Again, another illocutionary force hedge can be seen through the conditional subordinators (as long as) in "as long as I'm the president". Unfortunately, no translation into Arabic has found (The Guardian).

https://youtu.be/7zatCqqRY_I

\section{3) Trump on downplaying COVID-19: 'I don't want people to be frightened'}

\section{Published on 9 Sep 2020}

President Donald Trump, in an interview with journalist Bob Woodward, admitted to deliberately minimizing the seriousness of the novel coronavirus to the public, according to ABC NEWS reports on Wednesday. https://youtu.be/CUD6CM-C8ik

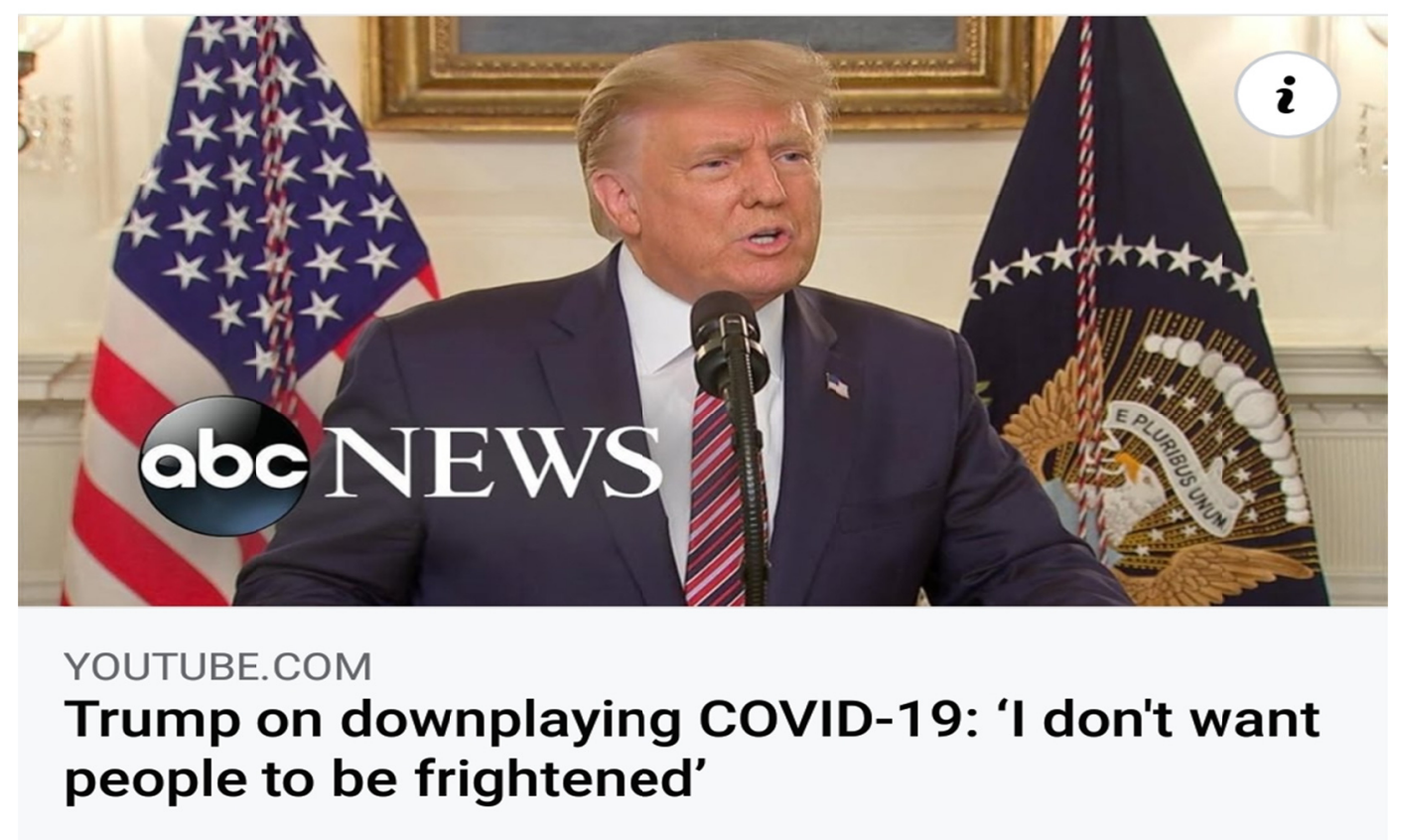

Figure 4. 'I don't want people to be frightened'

Trump said "Well, I think if you said in order to reduce panic, perhaps said so. In fact, is I'm cheer little for this country. I love our country, and I don't want people to be frightened. I don't want create panic as you say, and certainly, I'm not going to drive this country or the world to frenzy. We want to show confidence, we want to show, strength. We want to show strength as a nation, and that's what I've done; and we've done very well. We still panic; we don't want to jump up and down and start shouting that we have a problem, that is a tremendous problem scare everybody...."

According to Fraser's classification of hedges, hedges can be found as the following:

1) Illocutionary force hedges/Introductory phrases: "Well, I think..." since that "think" here expresses a verifiable fact that is the widespread panic in the USA and around the world (Schäffner, 1988, p. 187).

2) Illocutionary force hedges/Conditional clause expressing uncertainty/Model adverb (perhaps): "if you said in order to reduce panic, perhaps said."

3) Propositional hedges/In fact: "In fact, is I'm cheer......".

4) Illocutionary force hedge (Impersonal pronoun) little which is a singular indefinite-pronoun: "I'm cheer little for this country".

5) Illocutionary force hedge/Negation: I don't want people to be frightened. vs. I want people not to be frightened. "I don't want create panic as you say". vs. I want to create calmness. 
6) Illocutionary force hedge/Progressive form + Negation: "I'm not going to drive this country or the world to frenzy".

7) Propositional hedges: as you say, and certainly

8) Propositional hedges: very well

9) Illocutionary force hedge (Impersonal pronoun) everybody which is singular indefinite-body pronouns: “..., that is a tremendous problem scare everybody...."

The study has found one translation that is taken from AnaAlaraby TV as the following:

\section{(SL) English}

"Well, I think if you said in order to reduce panic, perhaps said so. In fact, is I'm cheer little for this country. I love our country, and I don't want people to be frightened. I don't want create panic as you say, and certainly, I'm not going to drive this country or the world to frenzy. We want to show confidence, we want to show, strength. We want to show strength as a nation, and that's what I've done; and we've done very well. We still panic; we don't want to jump up and down and start shouting that we have a problem that is a tremendous problem scares everybody"

\section{(TL) Arabic}

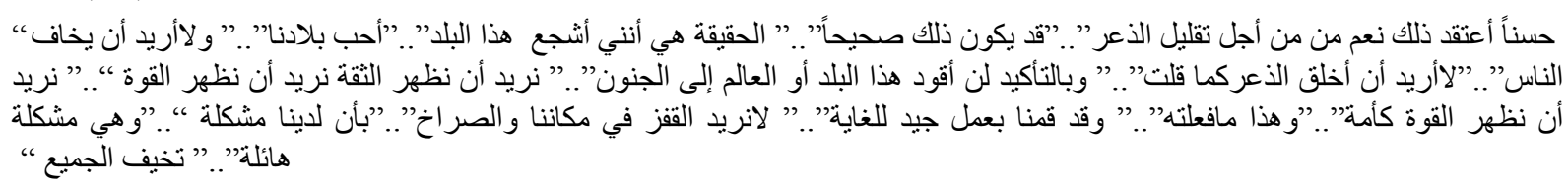

\subsection{Findings and Discussions}

The research used statistics to analyze the translated hedges used by president Trump in his conferences press from English into Arabic so that to find out which is the most common kind of hedges that has been used widely according to Fraser's classification as the following:

Table 1. Types of illocutionary force hedges used by U.S. President Donald Trump in COVID-19 conferences press according to Fraser Classification

\begin{tabular}{lll}
\hline Type & Frequency & Total Number \\
\hline Impersonal pronouns & 3 & $15 \%$ \\
Introductory phrases & 1 & $5 \%$ \\
Modal adverbs & 1 & $5 \%$ \\
Modal verbs & 3 & $15 \%$ \\
Epistemic verbs & 2 & $10 \%$ \\
Negation & 5 & $26 \%$ \\
Conditional subordinators & 1 & $5 \%$ \\
Progressive form & 2 & $10 \%$ \\
Conditional clause expressing uncertainty & 1 & $5 \%$ \\
Metalinguistic comment & 1 & $5 \%$ \\
Final Results & 20 & $100 \%$ \\
\hline
\end{tabular}

From the above stated table, the study has found that the illocutionary force hedges according to Fraser's classification; have widely used by president Trump in his press conferences, in that the (Impersonal pronouns) and (Modal verbs) have used about 15\%, whereas (Epistemic verbs) and (Progressive form) have used about 10\%. (Introductory phrases, Modal adverbs, Conditional subordinators, Conditional clause expressing uncertainty, and Metalinguistic comment) have used about $5 \%$, but on the other hand, (Negation) has used about $26 \%$; therefore, according to the above statistic, it is the most type of illocutionary force hedges that has used widely by Trump's press conferences. 
Table 2. Types of propositional hedges used by U.S. President Donald Trump in COVID-19 conferences press according to Fraser Classification

\begin{tabular}{lll}
\hline Propositional hedges & Frequency & Total Number \\
\hline Very & 3 & 37.5 \\
About & 1 & 12.5 \\
Really & 1 & 12.5 \\
In fact & 1 & 12.5 \\
as you say & 1 & 12.5 \\
Certainly & 1 & 12.5 \\
Final Results & 8 & $100 \%$ \\
\hline
\end{tabular}

In Table 2, the study has found that the propositional hedges according to Fraser classification; have used less by president Trump in his press conferences as the following: (very) has used about $37.5 \%$; whereas the others, i.e., (about, really, in fact, as you say, certainly) each one of them has used about $12.5 \%$. According to the above statistic, it is the less type of hedges that has used widely by Trump's press conferences.

\section{Conclusions}

The research has concluded the following:

1) Hedge can be defined as the rhetorical strategy by which the political speaker shows that there is a shortage of obligations to the truth value of the speech.

2) Statistics of this research have made on three different types of political press conferences interviews conducted with U.S. President Donald Trump about coronavirus with their translations into Arabic. They found that the illocutionary force hedges have widely used about $20 \%$ by president Trump more than the propositional hedges which have used about $8 \%$ according to Fraser's classification of hedges.

3) The research found many mistakes in the first and third translations of the first conference's interview which has conducted with president Trump about coronavirus, whereas the second translation was good. Therefore, political translator should be very accurate, sensitive when translating these terms according to Newmark (1982, pp. 375-391)," translators of political texts should be "sensitive and critics of language". Based on this, the use of these hedges by most politicians will make the statements fuzzier; and as a result the translations will be less intense and modifying the original intention.

4) Hedges can be considered as one of the most important linguistic phenomena because it can widely be used as a way of expressing points of view in political discourse. It's also can be used by speakers in their daily life such as doctors, teachers, lawyers, but in particular politicians in their speeches, TV-interviews and press-conferences.

\section{Acknowledgments}

The author is very grateful to the University of Mosul/College of Dentistry/ Basic Sciences for their provided facilities, which helped to improve the quality of this work.

\section{Dedication}

To My Wonderful Mother Bashaeer Fahad Al-Chalabi

The Ever Lasting Fountain of Love and Kindness!!

The Woman who battled Covid-19 until the last moment!!

May you rest in peace!!

\section{References}

Aijmer, K. (1987). Discourse variation and hedging. Costerus, 57, 1-18. https://doi.org/10.1163/9789004490192_003

Baker, M. (2006). Translation and conflict: A narrative account. GB: Routledge. https://doi.org/10.4324/9780203099919

Blum-Kulka, S. (1985). Modifiers as indicating devices: The case of requests. Theoretica Linguistics, 12(2/3), 213-229. https://doi.org/10.1515/thli.1985.12.2-3.213

Brown, P., \& Levinson, S. (1987). Politeness: Some Universals in Language Usage. Cambridge: Cambridge University Press. https://doi.org/10.1017/CBO9780511813085

Clemen, G. (1997). The concept of hedging: Origins, approaches and definitions. In S. Hartmut \& M. Raija 
(Eds.), Hedging and Discourse (pp. 80-97). Berlin: de Gruyter. https://doi.org/10.1515/9783110807332.235

Davis, R. (1992). The Press and American Politics: The New Mediator. White Plains, New York: Longman.

Fetzer, A. (n.d.). Hedges in context: Form and function of sort of and kind of (Forthcoming). In S. Stefan (Ed.), Vagueness in Language. Bingley: Emerald Publishing.

Fraser, B. (2010). Chapter 11. Hedging in political discourse. In U. Okulska \& C. Piotr (Eds.), Perspectives in Politics and Discourse (pp. 201-214). https://doi.org/10.1075/dapsac.36.16fra

Fraser, B. (n.d.). A brief history of hedging (Forthcoming). In S. Stefan (Ed.), Vagueness in Language. Bingley: Emerald Publishing.

Holmes, J. (1984). Hedging your bets and sitting on the fence: Some evidence for hedges as support structures. Te Reo, 27, 47-62.

House, J., \& Kasper, G. (1981). Politeness markers in English and in German. In C. Florian (Ed.), Conversational Routines (pp. 157-185). The Hague: Mouton de Gruyter. https://doi.org/10.1515/9783110809145.157

Hovy, D. (2004). Hedges. Retrieved June 12, 2012, from http://www.dirkhovy.com/portfolio/papers/

Hyland, K. (1996). Writing without conviction? Hedging in science research articles. Applied Linguistics, 17(4), 433-454. https://doi.org/10.1093/applin/17.4.433

Jalilifar, A. R., \& Alavi, M. (2011). Power and Politics of Language Use: A Survey of Hedging Devices in Political Interviews. The Journal of Teaching Language Skills, 43-49.

Kernell, S. (1986). Going Public: New Strategies of Presidential Leadership. Washington, D.C.: Congressional Quarterly Press.

Lakoff, G. (1972). Hedges: A study in meaning criteria and the logic of fuzzy concepts. CLS, 8, 183-228.

Lakoff, G. (1973a). Lexicography and generative grammar I: Hedges and meaning criteria. Annals of the New York Academy of Sciences, 211, 144-153. https://doi.org/10.1111/j.1749-6632.1973.tb49487.x

Lakoff, G. (1973b). Language and Woman's Place. Cambridge University Press. https://doi.org/10.1017/S0047404500000051

Loewenberg, I. (1982). Labels and hedges: The metalinguistic turn. Language and Style, 15(3), 193-207.

Lyons, J. (1977). Semantics. Cambridge: Cambridge University Press.

Missikova, G. (2008). Maxim Hedges in Literary Text: A Translational Perspective. Discourse and Interaction, $76-79$.

Munday, J. (2008). Style and ideology in translation: Latin American writing in English. New York: Routledge.

Munday, J. (2012). Evaluation in translation: Critical points of translator decision-making. London, England \& New York, NY: Routledge. https://doi.org/10.4324/9780203117743

Newmark, P. (1982). The translation of authoritative statements: A discussion. Meta, 4, 375-391. https://doi.org/10.7202/003728ar

Partington, A. (2003). The Linguistics of Political Argument. The Spin-doctor and the Wolf-pack at the White House. London: Routledge.

Pellby, E. P. (2013). Hedging in Political Discourse: An Analysis of Hedging in an American City Council Academin for Utbildning Och Ekonomi. Avdelningen for humaniora, 1-29. Retrieved from http://www.diva-portal.org/smash/get... FULLTEXT01.pdf

Prince, E., Bosk, C., \& Frader, J. (1982). On hedging in physician-physician discourse. In P. Robert di (Ed.), Linguistics and the Professions (pp. 83-97). Norwood/NewJersey: Ablex.

Safwat, S., \& Faiq, A, (2018). Hedging in Doctor-Patient Communication: A Pragmatic Study. International Journal of Humanities and Cultural Studies. https://doi.org/10.26750/jru.1020

Salager-Meyer, F. (1995). I think that perhaps you should: A study of hedges in written scientific discourse. The Journal of TESOL France, 2(2), 127-143.

Schäffner, C. (1998). Hedges in political texts: A translational perspective. In L. Hickey (Ed.), The pragmatics of translation. GB: Cornwell

Schäffner, C. (2008). 'The Prime Minister said ...': Voices in translated political texts. Synaps, 22, 3-25. 
Silberstein, S. (2004). War of Words. London: Routledge. https://doi.org/10.4324/9780203341421

Smith, C. (1990). Presidential Press Conferences: A Critical Approach. New York: Praeger. The 2007 Presidential Press Conferences (the total of 30). Retrieved April 30, 2008 from http://www.presidency.ucsb.edu/

Yan, L. M., Kang, S., Guan, J., \& Hu, S. C. (2020). Unusual Features of the SARS-CoV-2 Genome Suggesting Sophisticated Laboratory Modification Rather Than Natural Evolution and Delineation of Its Probable Synthetic Route. Rule of Law Society \& Rule of Law Foundation, New York, NY, USA.

https://www.facebook.com/SkyNewsArabia/videos/202190707711054/

https://m.facebook.com/story.php?story_fbid=117234903231864\&id=111436997144988

https://m.facebook.com/story.php?story_fbid=2647169308849950\&id=1948305112069710

https://youtu.be/7zatCqqRY_I

https://www.theguardian.com/us-news/2020/mar/20/trump-coronavirus-question-attack-reporter-over-fears

https://youtu.be/CUD6CM-C8ik

https://m.facebook.com/story.php?story_fbid=2799756206924592\&id=1948305112069710

https://m.facebook.com/story.php?story_fbid=630313624545570\&id=588565647885123

\section{Copyrights}

Copyright for this article is retained by the author, with first publication rights granted to the journal.

This is an open-access article distributed under the terms and conditions of the Creative Commons Attribution license (http://creativecommons.org/licenses/by/4.0/). 